\title{
Corela
}

Cognition, représentation, langage

HS-19 | 2016

Le point de vue pris au mot

\section{Language and language : Approaches to metaphor}

John Stewart

\section{OpenEdition}

Journals

Édition électronique

URL : http://journals.openedition.org/corela/4417

DOI : 10.4000/corela.4417

ISSN : 1638-573X

Éditeur

Cercle linguistique du Centre et de l'Ouest - CerLICO

\section{Référence électronique}

John Stewart, «Language and language : Approaches to metaphor », Corela [En ligne], HS-19 | 2016, mis en ligne le 08 juin 2016, consulté le 23 avril 2019. URL : http://journals.openedition.org/ corela/4417 ; DOI : 10.4000/corela.4417

Ce document a été généré automatiquement le 23 avril 2019.

\section{(c) (i) (2)(2)}

Corela - cognition, représentation, langage est mis à disposition selon les termes de la licence Creative Commons Attribution - Pas d'Utilisation Commerciale - Partage dans les Mêmes Conditions 4.0 International. 


\title{
Language and language: Approaches to metaphor
}

\author{
John Stewart
}

«There's glory for you ! » said Humpty Dumpty. «I don't know what you mean by 'glory', » Alice

said.

Humpty smiled contemptuously. « Of course you don't - till I tell you. I meant 'there's a nice knock-

down argument for you!' »

« But 'glory' doesn't mean 'a nice knock-down argument,' » Alice objected.

« When I use a word, Humpty said in a rather scornful tone, « it means just what I choose it to mean - neither more nor less. » "The question is, said Alice, whether you can make words mean so many different things. "

« The question is, said Humpty, which is to be master - that's all. » Lewis Carroll (1871).

\section{Introduction}

English speakers have some difficulty in appreciating the difference between « language » and « language ». With good reason, one might be tempted to say. The point, however, is that in French there are two words - «langue» and «langage " - which do not necessarily have the same meaning. The work of Pierre-Yves Raccah is characterized by great precision and rigour; and here we have a case in point. He has established a terminology in which "langue" refers to a natural language, such as French or English; whereas "langage" refers to a formal language, the language of logic. Statements in a natural language are generally "phrases", which means that their interpretation is always 
up for negotiation, and will depend heavily on the contextual situation. Statements in a formal language, by contrast, which take the form of logical propositions, have at least the appearance ${ }^{1}$ of having a unique interpretation which is context-free.

Pierre-Yves Raccah has put this important distinction to good use in an article which I will take as the focal point of this paper: A non paradoxical conception of metaphor, based on a non metaphorical conception of paradox (Raccah 2011). In this article, Raccah clearly states three objectives, which may at first sight seem to be not only difficult to accept, but which may also appear disconnected. There are thus actually four objectives; since to the first three there must be added the objective of showing that they are indeed connected. Thus, Raccah proposes:

- to defend and to illustrate the idea according to which the presence of a paradox in a reasoning indicates a dimensional flattening, in other words that there is a failure to take into account an essential conceptual difference, in one of the steps in the reasoning;

- to show that the usual conception of the notion of metaphor engenders a paradox: he will conclude that it rests on a confusion;

- to propose a way of conceiving the notion of metaphor, which avoids this paradox by taking seriously distinctions which are overlooked in the classical conception: he will conclude that there is no linguistic conception of metaphor;

- to present theoretical tools which make it possible to integrate this conception of metaphor in a descriptive semantics sufficiently rigorous to avoid such dimensional flattening: he will conclude that the first three objectives are actually intimately connected.

3 We can thus see that Raccah is precise and rigorous, not only at the level of terminology, but also at the level of the construction of his argument. However, in this paper I shall not attempt to follow through the argument presented by Raccah in all its details; and this, for two reasons. Firstly, to do so would be (at best) to repeat what Raccah has himself so clearly expressed. The second reason is that I myself have some difficulty in following through the thread of the argument; although I agree with what I understand of the gist of it, I get a bit lost in some of the details. This is surely due essentially to my own limitations; for cultural reasons, related to my pragmatic Anglo-Saxon background, I am not at ease beyond a certain level of abstraction. What I therefore propose to do, is to express in my own words what I understand as Raccah's principle conclusion; and then to present a complementary approach, based on the paradigm of Enaction, which as I see it leads essentially to the same conclusion (section 2). Finally, in section 3, I propose to address a new question which (as it seems to me) arises for both approaches.

\section{An alternative approach to metaphor}

I take it that the principle conclusion of Raccah's argument is this: "metaphor", as a linguistic conception, does not exist. The reason for this is that in natural language, everything is metaphor; and because of this, nothing (in particular) is metaphor. How does the paradigm of Enaction approach this question?

5 The paradigm of Enaction is a newcomer on the stage of Cognitive Science; its ambition is neither more nor less than to rival with the traditional "Computational Theory of Mind" TCM - (and its neo-connexionist variants) as a possible framework for addressing the question of cognition as a whole. One of the very real merits of the CTM is that it offers a genuinely transdisciplinary approach, crossing the barriers of psychology, neuroscience 
and linguistics; it does this by taking "the computer" as a basic metaphor (?!) for cognition in general. The paradigm of Enaction must therefore do at least as well; it achieves its own form of transdisciplinarity by taking an alternative metaphor, that of living organisms, as its basis. The research programme of Enaction then consists of following through, step by step, the evolutionary path that leads from the origin of life right up to the present day. Beyond these liminary remarks, it is not my intention here to present the paradigm of Enaction; for this, interested readers are referred to Maturana and Varela (1980), Varela et alii (1991) and Stewart et alii (2010). Here, I will focus on just two steps that are particularly relevant for our question concerning language and metaphor.

The first of these steps occurred quite early in evolution: it may be dubbed "animal communication". This is defined as a situation where certain environmental conditions trigger the emission of a signal; the perception of this signal by another animal modulates the actions of the receiver; and the combination of the particular conditions which trigger the emission of the signal, the particular actions taken, and the ecological situation leads to a co-ordination of actions that improves the viability of the animals concerned (Maturana and Varela 1980). Several points may be noted here. Firstly, the material nature of the signal is quite irrelevant; all that counts is the dynamics that are engendered. Linguists make a big point about the "arbitrary" nature of semiotic signals; but although as we shall see there are major qualitative differences between animal communication and human language, the arbitrary nature of the sign is not among them. Secondly, the animals concerned do not have any intention to communicate; the coordination of actions occurs effectively even though the animals have no understanding of what they are doing. This can be illustrated by experimental modifications of the situation such that the emission and perception of the signals no longer serves any useful purpose; in this case, even relatively evolved animals such as vervet monkeys go on producing their signals and behavioural reactions "as usual", and simply do not notice that anything is amiss. It is fair to conclude that in the case of "animal communication", both the emission of signals and the behavioural reactions are highly stereotyped reactions common to all normal members of the species; as such, they can perfectly well be explained by natural selection, and do not involve any "understanding" or "intention to communicate".

7 The second step is the emergence of language in the full sense of the term; this occurred much later, as a key element in the process of hominisation. By contrast with animal communication, human language is dramatically not stereotyped. Firstly, because of the combinatorial mechanisms at work (phonemes or letters into words, words into sentences), the number of different "signals" is stupendous. The number of different semantic meanings is even greater. Considering the word as a unit, the meaning of a word can vary according to its linguistic context (the neighbouring words with which it is combined) and even more according to its pragmatic context. Taking this into due account, one could seriously put forward the hypothesis that no word has ever been used twice to mean exactly the same thing.

8 This, however, immediately raises a problem. Animal communication functions (without understanding) because it is stereotyped. If human language is not stereotyped, how do human beings ever communicate correctly by talking? A part of the answer is that in general we probably understand each other far less than we fondly imagine. Garfinkel (1967) has impishly pointed out that in the course of normal conversation, the socially 
acceptable thing to do is to accept to have only a very vague and imperfect understanding of what is actually being said, and riding the wave of good faith that things will become "sufficiently clear" as we go along. Arguably, some of the most significant moments of communication occur when speakers identify a misunderstanding; paradoxical though it may seem, what happens is that they then realize that up until that point, they had been misinterpreting each other (with the best of intentions, of course). My point here is not nihilistic; I am not saying that we do not understand each other at all, only that our understanding is not, and cannot be, "100\% perfect" (as the "information-transfer" model dear to the Computational Theory of Mind would suggest is possible).

If we accept that a verbal utterance radically underdetermines the meaning to be communicated, how can some degree of communication nevertheless occur? This is where the intention to communicate comes in. Firstly, the hearer puts great creativity into inventing, imagining, guessing what the speaker might be trying to say. Of course, this is (at best) a hypothesis; the communication can only be consolidated if there is some feedback. This is why such phrases as: "Do you mean that...." (followed by a paraphrase); or "I don't understand what you mean at all, please say it again"; or (sometimes) "Yes, yes, I see, go on..." are so common in ordinary conversation. It is to be noted that these meta-linguistic messages - absolutely vital for linguistic inter-comprehension, on this account - are often replaced by facial gestures and mimics: a frown, a deliberate silence, a nod of the head, winking the eyes, and so on. Such gestures are not usually counted as "linguistic" (they are not words); but if this theory is right, such meta-linguistic signals are actually at the core of what is characteristically linguistic. Thus, linguistic communication is governed by a (mutual) intention to communicate. It is thus, theoretically, a second order communication about the status of the first-level intercomprehension. This discursive elaboration is meant to put some flesh on the rather dry definition of a "linguistic domain" by Maturana and Varela (1980): language is a secondorder meta-communication, a co-ordination of co-ordination of actions.

Having thus sketched out a theory of language as it appears in the paradigm of Enaction, we can now return to the question of metaphor. Hopefully it will not be necessary to labour the point. If the meaning of a word is never unambiguously pre-defined, but is always up for redefinition and negotiation; if a word can always mean "just what one chooses it to mean, neither more nor less"; then although not all speakers may constantly go to the length of Humpty Dumpty, it follows that "metaphor" is not the exception but the rule. As Lakoff and Johnson (1980) and Lakoff (1987) have said, "all is metaphor". But if indeed "all is metaphor"; if "metaphor" is not a peculiar figure of speech, but simply the norm, then it does not call for any particular explanation or construal; and in this sense, as Raccah (2011) points out, it does not exist.

\section{A return to literal sense}

11 Now if "metaphor" as a particular figure of speech does not exist, we come to rather unexpected question: what about literal sense?! The conventional view is that "literal sense" is the norm which does not require any particular explanation, and "metaphor" the peculiar figure of speech which does call for elucidation. If we turn this on its head, as we propose doing here, and consider that "metaphor" is the norm which does not require explanation, then there is still something we do have to explain: and this is "literal 
sense", or at any rate the appearance of "literal sense" (hence the scare-quotes around "literal").

An analogy may help us here. In the field of Science (or more precisely, in epistemology), it is usual to consider that "objective reality" exists and is what it is (independently of anything that may or may not be known about it); and that "true scientific facts" are neither more nor less than faithful representations of this reality. However Latour and Woolgar (1979), based on careful observation of what actually goes on in a real scientific laboratory over a period of time, have provided a somewhat different account. They note that during the period when scientific knowledge is actually being generated, all scientific statements start their career as hypotheses; at this stage, the scientists themselves clearly recognize that these hypotheses spring from their own subjective imagination (to anticipate, this would seem to be indeed of the same order as the creative imagination deployed by the partners in a conversation trying to imagine what the other person might be trying to express). Coming back to the scientific laboratory, the majority of these hypotheses are abandoned: sometimes rapidly, if a new experiment refutes them definitively; more often, they die a slow and lingering death simply because no-one finds it worthwhile to conduct experiments designed to test them. However in a rather small majority of cases, the hypothesis stays around, and even prospers if it successfully avoids refutation in a sufficient number of well-publicized experiments where it made surprising predictions. If a consensus forms in the relevant scientific community, the "factual" status of a statement stabilizes; and if this lasts for a sufficient time, then two remarkable processes called "splitting" and "inversion" occur. Firstly, the statement "splits" into two, and sends a copy of itself into "the real world out there". If one can catch the process at this critical point (which is difficult, since it usually only lasts a short time), the relation between the hypothetical statement and the copy is startlingly clear: since it is rigorously impossible to say anything about the "real object out there" that is not just repeating the terms of the statement, the "object" is nothing other than a derivative carbon-copy of the initial statement. However, very rapidly (so rapidly, indeed, that the sleight of hand generally escapes notice), a second event occurs: the relation between the statement and the "copy" is inverted so that the statement is presented, rhetorically, as the "copy" of the "real object out there". Thus, scientific facts have the peculiar property that the final stages of their construction consist of creating a "referential impression" which belies their own nature as social constructions; and the adequatio rei et intellectus between object and statement becomes a miraculous matter for philosophical wonderment. The sad truth is, of course, that this marvelous "correspondence" derives quite simply from the fact that during its genesis, the "real object out there" first arose as a perfect carbon-copy of the scientific statement. If anyone should doubt Latour and Woolgar's account, it is interesting to observe what happens when, as is sometimes the case, a later experiment does refute the hypothesis. Any selfrespecting "real object" would not take this lying down, and would stubbornly stay around (after all, it is in its very nature to be "above" the doings of mere mortal men); but what actually happens in practice is that it dutifully and discreetly fades back into oblivion.

13 Returning to our question of "literal meanings", it may be that something of the same sort is going on. To harp on our main point: in the course of natural language discourse, all the words are "metaphors" in the sense that they have no unique, pre-defined meaning; the meaning is "up for grabs" each time, and calls for active interpretation (and 
guessing, and negotiation). An appearance of "literal meaning" will arise when the situation becomes stereotyped (ironically, this is not really an advance, but rather a retreat to the situation of "animal communication" as we have characterized it above). It is in such circumstances that the word in question will project a "double" of itself out into some "pre-defined" zone of absolute meaning; and then an operation of "inversion" will make it seem that the word "refers" to this stable meaning. Another way of saying this is that the word becomes a "dead metaphor". Fortunately, this is never the end of the story; because a "dead metaphor" can always come to life again if one departs from the stereotype and audaciously gives it a new meaning. This is not quite as hard as it may seem; we don't need to have the impudent insolence of Humpty Dumpty; in practice, we do it all the time without even noticing...

In conclusion, language may be at its best when we are half-way between a metaphor and a literal meaning. As Raccah (2013) has remarked, with his usual perspicacity, a good metaphor is like a good joke: totally unexpected when you first come across it - but obvious once you have seen it.

\section{BIBLIOGRAPHIE}

Carroll Lewis, Through the Looking Glass, and What Alice Found There, Macmillan, London, 1871.

Garfinkel Harold, Studies in ethnomethodology, Englewood Cliffs, NJ, Prentice-Hall, 1967.

Lakoff George et Johnson Mark, Metaphors we live by, Chicago University Press, Chicago, 1980.

Lakoff George, Women, Fire and Dangerous Things: What Categories Reveal About the Mind, University of Chicago Press, Chicago, 1987.

Latour Bruno et Woolgar Steve, Laboratory life: the social construction of scientific facts, Sage, Beverly Hills, 1979.

Maturana Humbert R. et Varela Francisco J., Autopoiesis and cognition: the realization of the living, Reidel, Boston, 1980.

Raccah Pierre-Yves, « Une conception non paradoxale de la métaphore, s'appuyant sur une conception non métaphorique du paradoxe », in Simonffy, Zsuzsa (ed.), Le paradoxe et ses usages, Tinta Könyvkiadó, Budapest et Éditions Lambert-Lucas, Limoges, 2011, pp. 27-45.

Raccah Pierre-Yves, « Humour et métaphore : quelques éléments d'une analogie pour la construction d'un sens inattendu. Illustration sur un corpus de citations de George Bernard Shaw ", Colloque international : 6èmes rencontres de Sémantique et Pragmatique, Orléans, juillet 2013.

Stewart John, Gapenne Olivier et Di Paolo Ezequiel A. (eds.), Enaction: Toward a New Paradigm for Cognitive Science, MIT Press, Boston, 2010.

Varela Francisco, Thompson Evan et Rosch Eleanor, The Embodied Mind, MIT Press, Boston, 1991. 


\section{NOTES}

1. I say they have the "appearance " of being context-free, because actually they themselves function in what is a very particular context, the one that has been formally set up by a community of logicians...

\section{RÉSUMÉS}

Des Anglophones peuvent éprouver quelques difficultés à comprendre la différence entre « langue » et « langage », car en anglais il existe un seul mot pour les deux, à savoir « language ». L'œuvre de Pierre-Yves Raccah est caractérisé par une très grande précision et rigueur ; cela est bien illustré par la terminologie qu'il a établi selon laquelle le terme « langue » correspond à une langue naturelle comme le Français ou l'Anglais; alors que le terme «langage " renvoie à un langage formel, le langage de la logique. Les énoncés dans une langue naturelle sont généralement des "phrases", ce qui signifie que leur interprétation appelle toujours une négociation et dépend fortement de la situation contextuelle. Par contre, les énoncés dans un langage formel prennent la forme de propositions logiques, qui possèdent apparemment une seule interprétation - quoique, il convient de le préciser, cette apparence dépend en réalité d'un contexte bien particulier, celui qui est établi par la communauté des logiciens.

Raccah (2011) a déployé cette distinction importante dans un article qui constitue le point focal de cette contribution. Raccah y présente un argument bien structuré, qui le conduit à conclure que « la métaphore n'existe pas». La raison est que dans les langues naturelles, tous les mots sont normalement des métaphores; il s'ensuit que « la métaphore », comme trope particulier qui appelle une explication, n'existe effectivement pas. Dans ma contribution, je propose de présenter une approche complémentaire, prenant comme cadre le paradigme de l'Énaction en Sciences Cognitives, qui conduit à une conclusion sensiblement identique. Finalement, je propose de formuler une nouvelle question qui se pose si l'on considère que «la métaphore " est normale; il s'agit du statut des "énoncés littéraux» qui, par une ironie du sort suite au renversement de la situation, deviennent à leur tour problématiques.

The work of Pierre-Yves Raccah is characterized by great precision and rigour; this is well illustrated by the terminological distinction he has established between natural language (such as French or English), and formal language as employed by logicians. The statements in a natural language are generally "phrases", which means that their interpretation is always a matter for negotiation and depends strongly on the contextual situation. By contrast, the statements in a formal language take the form of logical propositions, which apparently possess only a single interpretation - although, it may be pointed out, this appearance actually depends on a very particular context, that constructed by the community of logicians. This distinction can be difficult for English-speaking persons to grasp, because in English there is only one word "language" - whereas in French there are two, "langue" and "langage".

Raccah (2011) has deployed this important distinction in an important article which constitutes the focal point of this contribution. Raccah presents a precisely structured argument to the effect that "metaphors do not exist". The reason is that in natural language, all the words are normally 
metaphors; it follows that a "metaphor", as a distinctive figure of speech which calls for explanation, does indeed not exist. In my contribution, I propose to present a complementary approach, taking as framework the paradigm of Enaction in Cognitive Science, which comes to essentially the same conclusion. Finally, I propose to formulate a new question which arises if one considers that "metaphors" are normal: this concerns the status of "literal statements" which, by an irony of fate consequent on a reversal of the situation, become in their turn problematical.

INDEX

Keywords : natural language, formal language, metaphor, literal statement

Mots-clés : langue naturelle, langage formel, métaphore, énoncé littéral, Enaction

\section{AUTEUR}

JOHN STEWART

CRED, Université de Technologie de Compiègne 